\title{
The Role Of Flextime Appeal On Family And Work Outcomes Among Active And Non-Active Flextime Users: A Between Groups And Within Groups Analysis
}

Joseph F. Rocereto, Monmouth University, USA

Susan Forquer Gupta, Monmouth University, USA

Joseph B. Mosca, Monmouth University, USA

\begin{abstract}
The influence of schedule flexibility, including flextime, on work-family balance and job outcomes has been of great interest to both members of academia and practitioners. However, the role that the desirability of flextime has on such constructs has been largely ignored in past literature. Additionally, relatively few studies have investigated differences between work-family balance and job satisfaction among those who are actively using flextime and those who are not currently using flextime. Results of this study strengthen the need for an increased understanding of the role that flextime appeal serves in work-family balance and job satisfaction, and the impact that flextime has on enhancing these important work-related constructs. Other meaningful differences between flextime users and non-flextime users, including the roles of gender and the presence of children living at home are also explored.
\end{abstract}

Keywords: Flextime; Flextime Appeal; Work-Family Balance; Job Outcomes

\section{INTRODUCTION}

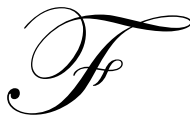

lexible work schedules or "Flextime" allows workers to adjust their work hours in order to attain a better balance between work and family life (Parayitam and Kalra 2008). Flextime has become a tool of organizations to reduce the negative impacts of trying to balance work and family demands (Nelson and Hitt 1992). Flextime has increasingly become a focal issue in firms due to the impact that the family interfering with work has decreasing job satisfaction (Wiley 1987), and, conversely, the high level of work interfering with family that leads to lower job satisfaction (Burke 1988).

Work-family balance, while an issue for all workers, has recently become associated with the problems experienced by mothers in the workforce. Research has identified that females with children at home experience more work-life conflict, more so than males with children at home (Ezra and Deckman 1996; Saltzstein, Ting, and Saltzstein 2001). These studies shed light on a real issue faced by workers, who will take primary responsibility for the raising of children. While this is an important piece of understanding the broader picture of employee work family balance and the impact it has on overall job satisfaction, it is only a piece of the puzzle. Work-family conflict can occur for many reasons, and the focus on child rearing responsibility as the center of the issues shows that organizations may be willing to accept child rearing as a legitimate conflict point, but what about other conflict points that may exist? Employees face a number of conflict points with their jobs including the stress of providing healthcare, and assistance to aging parents, siblings in addition to the accepted child rearing duties.

The purpose of this paper is to investigate the attitudes of employees toward flextime to better define the impact of flextime offerings on work-family balance and job satisfaction. We will also compare males and females, active users of flextime and non-active users, as well as the impact of dependent children. A final focus of this 
paper is to address the question: do offers of flextime schedules appeal to all employees or only to females with children?

\section{FOCAL CONSTRUCTS}

\section{Flextime Appeal}

Flextime appeal is a measure of how appealing it is to an employee to have flexible work schedules (Gainey and Clenney 2006). The measure is comprised of a set of variables that capture the appeal toward control over their own work schedule, the ability to adjust their work schedule, and something they look for in job opportunities.

\section{Work-Family Balance}

Work-family balance is a measure of an individual's attitude toward their ability to meet job and family demands experienced in life. Previous research strongly links work-family balance with overall job satisfaction. Work-family balance can be defined as the absence of work-family conflict in which the role pressures from the work and family domains are mutually compatible (Greenhaus and Beutell 1985). In general, a lack of work-family balance can lead to job behaviors that are a real cost to the organization including absenteeism, impaired performance and turnover, and therefore a strong driver of the implementation of flextime and other family friendly programs (Families and Work Institute 1998a; Ford Foundation 1997).

\section{Job Satisfaction}

Overall job satisfaction is an outcome of the employees' overall experiences of holding a job and the degree to which it satisfies their reasons for doing so. Job satisfaction measures provide a way to gauge employee happiness with their job and have been shown to be an important measure in predicting positive behavior on the job.

\section{SIMILARITIES AND DIFFERENCES BETWEEN ACTIVE AND NON-ACTIVE FLEXTIME USERS}

\section{Similarities between Groups}

\section{Flextime Appeal}

Gainey and Clenney (2006) found that Flextime Appeal had strong positive results (88\% strong positive appeal) across a graduate student sample that did not have a high percentage of dependents (only $13 \%$ of the respondents had dependents). This result supports the idea that there is broad appeal to flextime across the employee pool and not only for those with dependents. In addition, they found that flextime appeal was not related to demographic characteristics such as age, or gender, or marital status with results indicated strong support for the appeal of flextime across the board. Therefore:

H1: Flextime appeal will be strongly positive (high) for both active and non-active users of flextime.

The Relationship between Work-Family Balance and Job Satisfaction

Saltzstein Ting and Salzstein (2001) found that the positive impact of satisfaction with work-family balance on job satisfaction occurred across demographic groups, with a strong enough effect to equal the negative effect of job demands.

H2: For both active users and non-active users, work-family balance is positively related to job satisfaction. 


\section{Differences between Groups}

The Role of Flextime Appeal on Work-Family Balance and Job Satisfaction

With flextime appeal hypothesized as being high across the sample and workfamily balance having a strong positive relationship with job satisfaction (Saltzstein Ting and Salzstein 2001), we propose that:

H3a: For active users, flextime appeal will be positively related to (a) work-family balance and (b) job satisfaction.

H3b: For non-active users, flextime appeal will be negatively related to (a) work-family balance and (b) job satisfaction.

Levels of Work-Family Balance and Job Satisfaction

If flextime scheduling increases work-family balance which has a direct effect on job satisfaction (Ezra and Deckman 1996; Saltztein, Ting and Salzstein 2001), then:

H4a: Work-family balance will be higher for active users than for non-active users.

H4b: Job satisfaction will be higher for active users than for non-active users.

\section{THE IMPACT OF FAMILIES WITH CHILDREN WITHIN GROUPS}

\section{Non-Active Users with at Least One Child Living at Home}

Ezra and Deckman (1996) found that for both parents and nonparents, satisfaction with the balance between work and family (work-family balance) was important in job satisfaction, but for parents it was the most important factor impacting job satisfaction.

H5a: For non-active users, flextime appeal will be greater when at least one child is living at home.

H5b: For non-active users, work-family balance will be lower when at least one child is living at home.

H5c: For non-active users, job satisfaction will be lower when at least one child is living at home.

\section{Active Users with at Least One Child Living at Home}

We believe that for active users of flextime, there will be no significant differences regarding flextime appeal, work-family balance, and job satisfaction between those who have children at home and those who do not; (i.e., already using flextime, so appeal is same and flextime alleviates issues regarding work-family balance and job satisfaction even if children are at home).

H6: For active users, there will be no differences in the levels of (a) flextime appeal, (b) work-family balance, and (c) job satisfaction between respondents who have at least one child living at home and those with no children living at home.

\section{THE ROLE OF GENDER}

\section{Non-Active Users and Gender}

Gender differences have been found in work-life balance and job satisfaction. Some studies have found gender differences across the sample, others have only found gender differences when there are children at home (Ezra and Deckman 1996). Ezra and Deckman (1996) found that family friendly policies (including flextime 
scheduling) affect mothers and fathers very differently. Fathers were more satisfied than mothers with their work family balance.

H7a: For non-active users, flextime appeal will be greater for females than for males.

H7b: For non-active users, work-family balance will be lower for females than for males.

H7c: For non-active users, job satisfaction will be lower for females than for males.

\section{Active-Users and Gender}

While gender differences are expected in the absence of flextime usage, it is expected that no such differences will exist among active flextime users. For active users, it is likely that the flexibility afforded by flextime programs will mitigate any gender-related differences among constructs of interest. That is, both females and males will have similar levels of flextime appeal, work-family balance, and job satisfaction when the benefits of flextime programs are realized.

H8: For active users, there will be no difference between (a) flextime appeal, (b) work-family balance, and (c) job satisfaction between females and males.

\section{METHOD}

\section{Sample}

In order to increase the generalizability of the study, participants from several industries were recruited for the sample. These industries included: hospitality, healthcare, law, insurance, sales administration, retail, and law enforcement dispatchers. In total, 145 questionnaires were hand-delivered to organizations throughout these industries. A total of 135 questionnaires were returned. Of these questionnaires, 6 were unusable due to incomplete responses. Therefore, a total of 129 participants comprised the total sample resulting in a $95 \%$ response rate.

On average, the participants were 33.8 years old. Females comprised $60 \%$ of the sample, $83 \%$ of participants indicated that at least one child is currently living with them at home, and $70 \%$ currently have a spouse living with them. Roughly half of the participants indicated that they are currently using a form of flextime (55\%), while the remaining participants responded that they are not currently using any type of flextime (45\%).

\section{Measures}

All items used to measure study constructs used a 7-point Likert-type scale ( 1 = "strongly disagree"; 7 = "strongly agree"). Reliability is indicated by Chronbach's $\alpha$ for each scale. Construct correlations, means, and standard deviations for each group (those actively using a form of flextime and those who are not currently using flextime) throughout our measures are reported in Table 1.

Table 1. Construct Correlations, Means, and Standard Deviations

\begin{tabular}{|c|c|c|c|c|c|c|}
\hline \multirow{3}{*}{ Active Users } & \multirow[b]{3}{*}{ 1. Flextime Appeal } & \multicolumn{4}{|c|}{ Non-Active Users } & \multirow[b]{2}{*}{$\underline{\mathrm{SD}}$} \\
\hline & & $\underline{1}$ & $\underline{2}$ & $\underline{3}$ & Mean & \\
\hline & & $1 . \overline{0} 0$ & -0.69 & -0.36 & $\overline{6.21}$ & $\overline{1.25}$ \\
\hline & 2. Work-Family Balance & 0.66 & 1.00 & 0.43 & 3.14 & 2.09 \\
\hline & 3. Job Satisfaction & 0.26 & 0.76 & 1.00 & 5.35 & 1.03 \\
\hline & Mean & 6.24 & 5.93 & 6.51 & & \\
\hline & SD & 1.19 & 1.21 & 0.66 & & \\
\hline
\end{tabular}

Note: Descriptions for the Active Users group are below the diagonal whereas descriptions for the Non-Active Users group are above the diagonal 
Flextime Appeal was measured by a 4-item scale. Three of these items were adapted from Gainey and Clenney (2006) and included items such as, "Flexibility in work schedules is a major factor I look for in job opportunities". A fourth item was added to this scale which stated, "Flextime is an important work-related benefit for me". This scale showed acceptable reliability $(\alpha=.94)$.

Work-Family Balance was measured from a 5-item scale adapted from Greenhaus, Ziegert, and Allen (2009). Sample items included, "I am able to balance the demands of my work and the demands of my family life" and "I am satisfied with the balance I have achieved between my work and family life". One item was omitted from the analysis due to poor reliability. This item was the only reverse-scored item, and it is likely that respondents did not perceive it as such. The remaining 4 -item scale showed acceptable reliability $(\alpha=.98)$.

Job Satisfaction was measured from a 3-item scale. Participants were asked how satisfied they were with their job and the degree to which they liked working for their current employer. This scale included items such as, "All and all, I am satisfied with my current job". This scale showed adequate reliability $(\alpha=.92)$.

\section{Results}

Similarities between Groups

The first issue was to test for expected similarities regarding constructs of interest between those respondents who are actively using a form of flextime (active users) and those who are not currently using any form of flextime (non-active users). H1 predicted that flextime appeal would not differ between groups and that the desire for flextime opportunities would be high for both groups. One-way ANOVA was used to test for main effect differences between flextime appeal between groups, and results show that the desire for flextime was not significantly different between groups $\left(F(1,127)=.01, N S ; \mathrm{M}_{\text {active users }}=6.24\right.$ versus $\left.\mathrm{M}_{\text {non-active users }}=6.21\right)$. Additionally, flextime appeal for each group was statistically greater than the scale neutral point of 4 (active users, $t$ $=16.12, p<.05$; non-active users, $t=13.39, p<.05)$. Therefore H1 is supported.

$\mathrm{H} 2$ stated that the there would be a positive relationship between work-family balance and job satisfaction for both groups. Results of correlation analysis (see Table 1) support this hypothesis (active users, $r=0.76, p<.01$; non-active users, $r=0.43, p<.01$ ). As expected, work-family balance is positively related to job satisfaction regardless of flextime usage.

\section{Differences between Groups}

The next step was to investigate potential differences between the groups based upon flextime status (active versus non-active usage). $\mathrm{H} 3 \mathrm{a}$ and $\mathrm{H} 3 \mathrm{~b}$ predicted that, while flextime appeal would be relate to both work-family balance and job satisfaction for each group, the direction of these relationships would differ between groups. Specifically, H3a supposes positive relationships between flextime appeal and both work-family balance and job satisfaction, while $\mathrm{H} 3 \mathrm{~b}$ expects negative relationships between these corresponding constructs. Correlation analysis (see Table 1) supports these hypotheses. For active users, flextime appeal is positively related to work-family balance $(r=0.66, p<.01)$ as well as to job satisfaction $(r=0.26, p<.05)$, thus providing support for H3a. Conversely, in the case of non-active users, flextime appeal is negatively related to both work-family balance $(r=-$ $0.69, p<.01)$ and to job satisfaction $(r=-0.36, p<.01)$, supporting H3b. Therefore, flextime appeal serves and important, though distinctly different, role in resulting work-family balance and job satisfaction.

$\mathrm{H} 4 \mathrm{a}$ and $\mathrm{H} 4 \mathrm{~b}$ predict that flextime usage (active versus non-active) will impact the levels of work-family balance and job satisfaction. That is, $\mathrm{H} 4 \mathrm{a}$ expects that work-family balance will be greater for active users than for non-active users, and $\mathrm{H} 4 \mathrm{~b}$ expects the same differential levels of job satisfaction between groups. Results of oneway ANOVA to test for these differences between groups support both hypotheses. In regards to work-family balance, the main effect of flextime usage was significant $(F(1,127)=89.87, p<.05)$. That is, the usage of flextime increased respondents' work-family balance when compared to non-active flextime users $\left(\mathrm{M}_{\text {active users }}=5.93\right.$ versus $\left.\mathbf{M}_{\text {non-active users }}=3.14\right)$. Additionally, in regards to job satisfaction, the main effect of flextime usage was also significant $(F(1,27)=60.67, p<.05)$. Specifically, the usage of flextime increased respondents level of job 
satisfaction in comparison to non-active flextime users $\left(\mathrm{M}_{\text {active users }}=6.51\right.$ versus $\left.\mathrm{M}_{\text {non-active users }}=5.35\right)$. Therefore, both $\mathrm{H} 4 \mathrm{a}$ and $\mathrm{H} 4 \mathrm{~b}$ are supported.

Within Group Analysis: Effects of Children Living at Home and Gender

Non-Active Users and Children Living at Home

Another focus of this study was to assess the impact of respondents who have at least one child living at home on constructs of interest, and to investigate whether or not flextime usage mitigates any of these impacts. First, levels of flextime appeal, work-family balance, and job satisfaction were assessed among non-active flextime users, comparing these constructs between respondents who have at least one child living at home and those who have no children living at home. Next, the same comparisons were made between participants with at least one child living at home and those who have no children among active flextime users.

$\mathrm{H} 5 \mathrm{a}$ - $\mathrm{c}$ predicts that the presence or absence of at least one child living at home will moderate the constructs of interest. Specifically, H5a expects that, for non-active flextime users, the presence of at least one child living at home will increase the level of flextime appeal when compared to the same non-active users who do not have any children living at home. Results of one-way ANOVA show that the main effect of the presence of at least one child living at home on flextime appeal is significant $(F(1,55)=57.67, p<.05)$. That is, non-active flextime users who have at least one child living at home have higher levels of flextime appeal than non-active users with no children at home $\left(\mathrm{M}_{\text {child }}=6.74\right.$ versus $\left.\mathrm{M}_{\text {no child }}=4.73\right)$. Therefore, $\mathrm{H} 5 \mathrm{a}$ is supported.

$\mathrm{H} 5 \mathrm{~b}$ and $\mathrm{H} 5 \mathrm{c}$ predict that, for non-active users, work-family balance and job satisfaction, respectively, will be lower for respondents with at least one child living at home than for those who have no children living at home. One-way ANOVA show that the main effect of the presence of at least one child living at home is significant on both work-family balance $(F(1,55)=58.42, p<.05)$ and on job satisfaction $(F(1,55)=6.08, p<.05)$. In regards to work-family balance, non-active users with at least one child living at home report lower levels of work-family balance than reported by non-active users with no children living at home $\left(\mathrm{M}_{\text {child }}=2.25\right.$ versus $\left.\mathrm{M}_{\text {no child }}=5.63\right)$, supporting H5b. Similarly, non-active users with at least one child living at home show lower levels of job satisfaction than non-active users with no children at home $\left(\mathrm{M}_{\text {child }}=5.16\right.$ versus $\left.\mathrm{M}_{\text {no child }}=5.89\right)$, supporting $\mathrm{H} 5 \mathrm{c}$.

\section{Active Users and Children Living at Home}

While differences were expected regarding flextime appeal, work-family balance, and job satisfaction based upon the presence of at least one child living at home among non-active users of flextime, similar differences between these constructs are not anticipated among active user of flextime. For these respondents, the scheduling flexibility afforded to them via flextime is expected to mitigate the impacts of having at least one child living at home.

H6 formally states the expectation of the mitigating effects of flextime use on constructs of interest when at least one child is living at home. Specifically, H6 predicts that there will be no differences in flextime appeal, workfamily balance, and job satisfaction between respondents who report at least one child living at home and those who have no children living at home among active users of flextime. One-way ANOVA support these expectations. Results show that were no differences between those respondents with at least one child at home and those with no children at home regarding flextime appeal $\left(F(1,70)=0.40, N S ; \mathrm{M}_{\text {child }}=6.23\right.$ versus $\left.\mathrm{M}_{\text {no child }}=6.33\right)$, work-family balance $\left(F(1,70)=0.67, N S ; \mathrm{M}_{\text {child }}=5.97\right.$ versus $\left.\mathrm{M}_{\text {no child }}=5.54\right)$, and job satisfaction $\left(F(1,70)=0.00, N S ; \mathrm{M}_{\text {child }}=\right.$ 6.52 versus $\left.M_{\text {no child }}=6.50\right)$. Therefore, $\mathrm{H} 6$ is supported.

\section{The Role of Gender}

\section{Gender and Non-Active Users}

$\mathrm{H7a}$ - c predicts that, for non-active flextime users, gender will moderate the levels of flextime appeal, work-family balance, and job satisfaction. H7a supposes that flextime appeal will be greater for females than males 
when no form of flextime is currently being used. Results of one-way ANOVA supports this expectation $(F(1,55)=$ $4.42, p<.05 ; \mathrm{M}_{\text {female }}=6.49$ versus $\mathrm{M}_{\text {male }}=5.80$ ). Thus, $\mathrm{H7}$ a is supported.

$\mathrm{H} 7 \mathrm{~b}$ and $\mathrm{H} 7 \mathrm{c}$ predicted that work-family balance and job satisfaction, respectively, would be lower for females than males in the absence of flextime usage. Results of one-way ANOVA do not support these hypotheses. There was no significant difference in work-family balance between females and males in this group $(F(1,55)=$ $2.47, N S ; \mathrm{M}_{\text {female }}=2.79$ versus $\mathrm{M}_{\text {male }}=3.66$ ), and there was no significant difference in job satisfaction based upon gender for this group $\left(F(1,55)=0.39, N S ; \mathrm{M}_{\text {female }}=5.42\right.$ versus $\left.\mathrm{M}_{\text {male }}=5.25\right)$. Thus, $\mathrm{H} 7 \mathrm{~b}$ and $\mathrm{H} 7 \mathrm{c}$ are not supported.

\section{Gender and Active Users}

It was expected that the active usage of flextime would mitigate any potential differences between females and males regarding flextime appeal, work-family balance, and job satisfaction. Results of one-way ANOVA support these expectations. Specifically, there was no gender difference in flextime appeal for this group $(F(1,70)=$ $1.34, N S ; \mathrm{M}_{\text {female }}=6.37$ versus $\left.\mathrm{M}_{\text {male }}=6.04\right)$, work-family balance $\left(F(1,70)=0.62, N S ; \mathrm{M}_{\text {female }}=6.02\right.$ versus $\mathrm{M}_{\text {male }}=$ 5.79), nor job satisfaction $\left(F(1,70)=0.08, N S ; \mathrm{M}_{\text {female }}=6.50\right.$ versus $\left.\mathrm{M}_{\text {male }}=6.54\right)$. Therefore, $\mathrm{H} 8$ is supported.

\section{DISCUSSION AND CONCLUSIONS}

A primary purpose of this paper was to assess the role of flextime appeal in work-family balance and job satisfaction domains. Results indicate that flextime appeal plays a major role in these outcomes. While it is shown that all employees, regardless of their current flextime usage status, have a high desire for flextime, flextime appeal interacts quite differently with work-family balance and job satisfaction, depending upon their current flextime usage conditions. Specifically, study findings show that, for employees who are actively using flextime, flextime appeal is positively correlated with both work-family balance and job satisfaction. These positive relationships are likely due to the fact that the use of flextime increases the levels of work-family balance and job satisfaction, alike. Therefore, those employees who desire flextime, and have access to such job flexibility programs, enjoy higher levels of work-family balance and job satisfaction.

Flextime appeal, however, has quite a different relationship with work-family balance and job satisfaction in the absence of job-related flexibility offerings. For these employees, results indicate that flextime appeal is negatively related to both work-family balance and job satisfaction. These negative associations are likely due to the absence of flextime programs. It is likely that employees who desire flextime, but who are not offered such programs, experience lower levels of work-family balance and job satisfaction. These differential findings between groups indicate that the desire for flextime plays an important role in family and job-related outcomes.

An in-group look within both groups offers more details to these findings. Results indicate that, for employees who are not active flextime users, the presence of at least one child living at home affects the levels of flex appeal, work-family balance, and job satisfaction. Those employees who are not using flextime and have at least one child living at home have a significantly higher desire for flextime opportunities. Additionally, these same employees experience lower levels of work-family balance and job satisfaction. It appears that the absence of flextime programs leads to lower levels of work-family balance and job satisfaction for these employees, resulting in higher levels of flextime appeal.

Interestingly, the use of flextime appears to mitigate any differences in these constructs between employees who currently have at least one child living at home and those who have no children living at home. Flextime usage appears to alleviate both work-family balance and job satisfaction problems in cases where at least one child is living at home. Furthermore, it seems that these mitigating effects of flextime usage result in similar levels of flextime appeal, regardless of the presence or absence of children at home.

It was proposed that the absence of flextime would result in varying levels of flextime appeal, work-family balance, and job satisfaction based upon gender. While no gender differences were found in the realms of workfamily balance and job satisfaction for these non-flextime users, females who were not currently using flextime did 
possess higher levels of flextime appeal than their male counterparts. These findings further emphasize the importance of considering flextime appeal, as gender differences in this construct are directionally similar to such differences in family and job-related outcomes reported in previous flextime-related studies. Finally, as expected, it appears that active flextime use eliminates any gender differences among flextime appeal, work-family balance, and job satisfaction. Results show that those employees who are currently using a form of flextime have similar levels of each of these constructs.

\section{LIMITATIONS AND FUTURE RESEARCH}

As with any research endeavor, this study does have its limitations. First, the causality between constructs is not tested, as this study did not use an experimental design. Therefore, it is unclear whether flextime appeal influences levels of work-family balance and job satisfaction, or if current work-family balance and job satisfaction levels influence the desire for flextime among active and non-active flextime users. Future studies may wish to incorporate an experimental design to test for such causality.

Second, while the current sample consisted of a wide range of age groups, the mean age for the sample is roughly thirty-four. It may be possible that a sample with an older mean age may result in different findings. For instance, employees who have lengthier work experiences may have developed mechanisms to deal with family and work-related issues, regardless of their current flextime usage status. Therefore, future studies may wish to test for differences in family and work-related constructs based upon differences in age groups.

\section{AUTHOR INFORMATION}

Dr. Joseph F. Rocereto, Assistant Professor of Marketing at the Leon Hess Business School, Monmouth University, earned his Ph.D. from Drexel University. His research specializes in strategic branding, marketing communications, and managerial decision making. He has published in Advances in Consumer Research (ACR), the American Marketing Association Conference Proceedings, and other North American and international conferences.

Dr. Susan Forquer Gupta, Assistant Professor of Marketing and International Business at the Leon Hess Business School, Monmouth University, earned her Ph.D. from the University of Tennessee-Knoxville, and her M.S. and B.S. from the University of Missouri-Columbia. Her research focuses on measuring and comparing culture and its effects on managerial decision making (B2B), consumer decision making, as well as cultural differences in brand meaning and branding in global markets. She has published in the International Marketing Review (IMR), Journal of Business and Industrial Marketing (JBIM), and the Journal of Personal Selling and Sales Management.

Dr. Joseph B. Mosca, Associate Professor of Management in the Leon Hess Business School at Monmouth University earned his doctorate at NYU. Dr. Mosca specializes in Human Resource management, Human Relations, and active teaching methods, and is the recipient of seven teaching awards and three distinguished paper awards. His current research interests focus on developing hybrid courses, employee behavior, and jobs in the $21^{\text {st }}$ Century.

\section{REFERENCES}

1. Burke, R.J (1988). Some antecedents and consequences of work-family conflict, Journal of Social Behavior and personality, 3, pp 287-302.

2. Ezra, Marni, \& Deckman, Melissa. (1996). Balancing work and family responsibilities: Flextime and child care in the federal government. Public Administration Review, 56(2), 174.

3. Gainey, Thomas W ,\& Beth F Clenney. (2006). Flextime and Telecommuting: Examining Individual Perceptions. Southern Business Review, 32(1), 13-21.

4. Greenhaus, Jeffrey H. \& Nicholas J. Beutell. (1985). Sources of conflict between work and family roles. Academy of Management Review, 10(1), 76-88.

5. Greenhaus, J. H., Ziegert, J. C., \& Allen, T. D. (2009, April). When family-supportive supervision matters: Relationships between multiple sources of support and work-family balance. Poster paper presented at the International Community, Work \& Family Conference, April 16-18, 2009; Utrecht, the Netherlands. 
6. Parayitam, S., \& Kalra, N.. (2008). From Work-Family Conflicts To Psychological Stress, Job Satisfaction And To Life Satisfaction: A Proposed Integrative Model. Journal of Organizational Culture,

Communication and Conflict, 12(2), 49-63.

7. Nelson \& Hitt, 1992 [The discussion is based on Quick,J.C., Quick,J.D., Nelson, DL., \& Hurrell, J.J Jr (1997). Preventive stress management in organizations. Washington, D.C.: American Psychological Association].

8. Saltzstein, Alan L, Yuan Ting, \& Grace Hall Saltzstein. (2001). Work-family balance and job satisfaction: The impact of family-friendly policies on attitudes of federal government employees. Public Administration Review, 61(4), 452-467.

9. Wiley, D.L. (1987). The relationship between work-nonwork role conflict and job-related outcomes: Some unanticipated findings. Journal of Management, 13, pp.467-472. 
Journal of Business \& Economics Research-March, 2011 Volume 9, Number 3 NOTES 